\title{
Eastern Africa Standby Force's Efforts In Execution Of Its Mandate In Maintaining Peace And Security In Kenya And Somalia
}

\author{
Robert Gichangi Kabage, Prof.Kennedy Onkware, Prof.Crispinous Iteyo \\ Department of Peace and Conflict Studies, P.O Box 190-50100, Kakamega \\ DOI: 10.29322/IJSRP.10.11.2020.p10756 \\ http://dx.doi.org/10.29322/IJSRP.10.11.2020.p10756
}

\begin{abstract}
The nature and numbers of intrastate conflicts in the early nineties challenged regional security; thereby requiring a collective regional response. This explains the formation of a number of regional security mechanisms such as EASF with a mandate to maintain peace and security in the Eastern Africa region. Despite over a decade of its existence, the EASF efforts to tackle the seemingly intractable peace and security dilemmas in the region and especially in Kenya and Somalia have remained elusive and insignificant, making it more of a bystander. This study sought to address this gap. As for EASF efforts to enhance its capability to be able to maintain peace and security, the study found out that EASF has put in place a number of initiatives. The study therefore sought to evaluate Eastern Africa Standby Force's efforts in maintaining peace and security in Kenya and Somalia. This research paper is underpinned by theoretical framework utilizing power theory.
\end{abstract}

\section{INTRODUCTION}

$\mathrm{G}$ lobally, at the beginning of the Cold War, the United States and its European allies created a security organization that sought to deter the Soviet Union from further expanding beyond East Berlin. In 1949, the North Atlantic Treaty Organization (NATO) was formed and it served as the premier world security organization. The United States has been a central member of NATO with its role enhanced since the end of the Cold War. In recent conflicts, the United States has been involved in NATO military operations, particularly in Eastern Europe, South Asia, and North Africa. Lindberg (1963), noted that international actors that seek to attain their interests will require "systematic and durable cooperation" and institutions will seek "to attain their ends, including increasing their shares of gains from cooperation, through the use of political influence." Continentally, the ASF as a multidimensional force was formed to ensure continental stability. Since most conflicts on the continent are complex and of long duration, they call for a multifaceted approach and require capabilities to address not only security and military aspects, but also the political, humanitarian, developmental and legal/institutional dimensions of the conflicts. According to Darkwa (2017), the African Union came to life in July 2002. Nzau (2016), observes that the other effort by EASF in its mandate of maintaining peace and security in Kenya and Somalia is through cooperation with IGAD. It was founded in 1996 to replace Inter-
Governmental Authority on Development and Desertification (IGADD),

\section{THEORETICAL FRAMEWORK}

The study was underpinned by power theory. The theory was advanced by Morgenthau (1960), who emphasized on the importance of "the national interest" in politics among nations. He wrote "the main signpost that helps political realism to find its way through the landscape of international politics is the concept of interest defined in terms of power". It underscores the fact that individual states are able to invoke their domestic power to maintain peace and security within their territory. Additionally, Waltz (1986), observes that power is a key concept in realist theories of international politics, while conceding that 'its proper definition remains a matter of controversy.' While Gilpin (1981), describes the concept of power as 'one of the most troublesome in the field of international conflict' and moots that the 'number and variety of definitions should be an embarrassment to political scientists', there is however a widespread consensus among international conflict scholars on both the necessity of addressing the role of power in international interactions and the unsatisfactory state of knowledge about this trope-power (Guzzini, 2000; Barnett and Duvall, 2005; Berenskoetter and Williams, 2007). The power theory explains exertion of influence of one party, EASF, and therefore the efforts of group or individuals over another.

\section{RESEARCH METHODOLOGY}

This study adopted descriptive research design. Orodho (2003), defines descriptive design as a method of collecting information by interviewing or administering questionnaire to a sample population to get their attitude, opinion and habits on any variety of educational or social issues. This design was used to describe the demographic elements under study. It gave a detailed account of demographic characteristics of the respondents to the study. The descriptive approach aided in describing the status of the variables in objective one while showing how the variables relate in the natural setting (Creswell, 2009). The design was used to describe a compendium of efforts made towards EASF's mandate of maintaining peace and security in Kenya and Somalia. A total of 300 questionnaires were administered to the 
respondents. 255 were returned, while 45 were not returned. This implied that there was $85 \%$ response rate. This impressive rate was achieved due to the rigorous engagement of the respondents by the research assistants. The $15 \%$ who did not manage to complete the study was either due to busy schedules or failure to submit the questionnaires in time. The study findings are considered valid since, according to Mugenda and Mugenda (2003), a response rate of $50 \%$ is adequate for analysis and reporting. A response rate of $60-69 \%$ is considered to be good, while that of above $70 \%$ is excellent. So the response rate for this study was excellent (Mugenda and Mugenda, 2003).

\section{STUDY FINDINGS}

\section{* Strengthening of EASF Funding Support}

The study sought to find out if improving the financial support of EASF was an initiative used by EASF to enhance its capability of maintaining peace and security in Kenya and Somalia. Out of the 255 respondents, 204 (80\%) strongly agreed and $26(10 \%)$ agreed. On the other hand $18(7 \%)$ of the participants disagreed and 7 (3\%) strongly disagreed. Cumulatively $80 \%$ of the respondents agreed that strengthening the financial support of EASF was an effective effort to enhance EASF effectiveness in maintaining peace and security in Kenya and Somalia.

The results are as illustrated in figure 5.1.

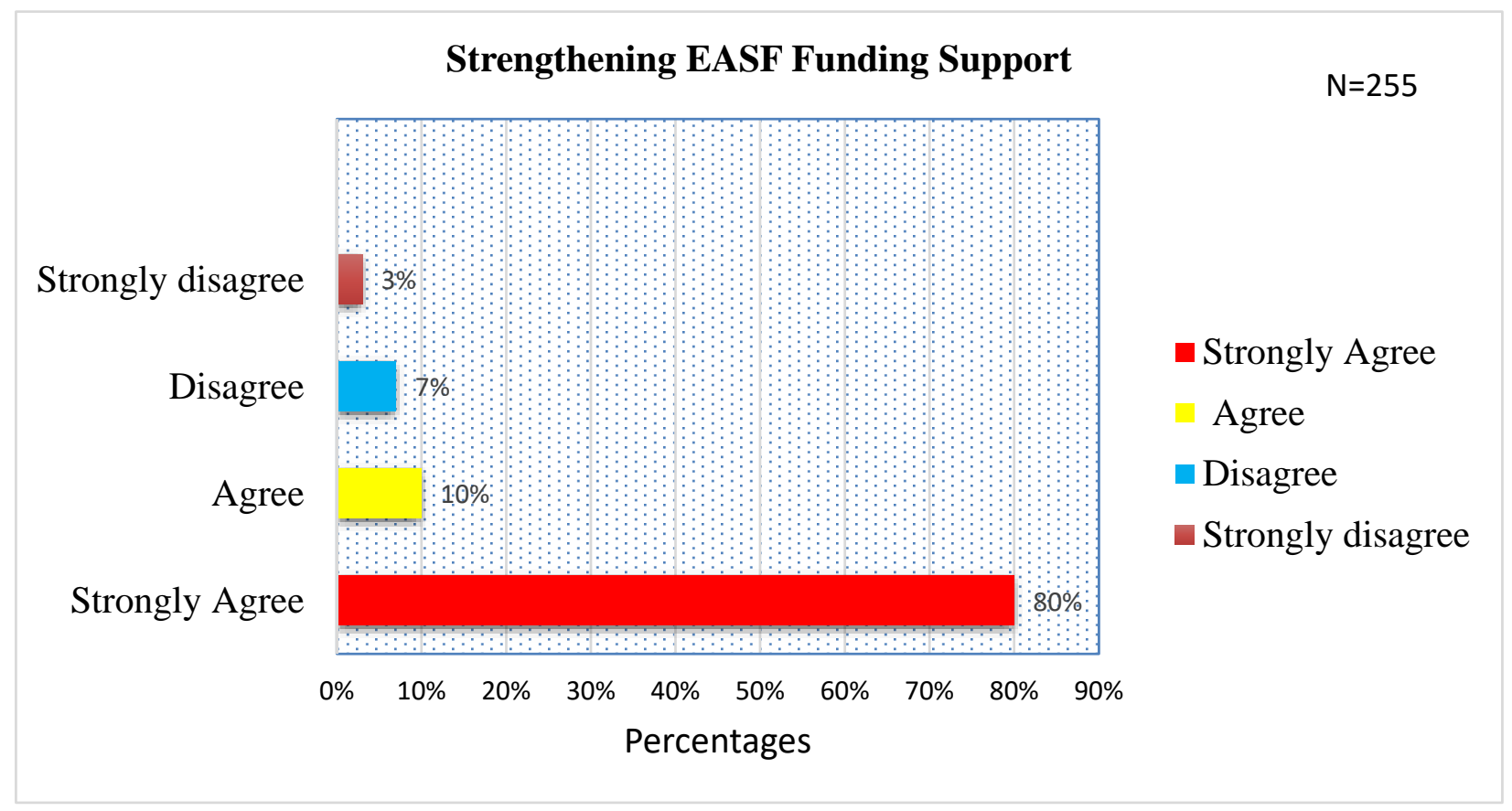

Figure 5.1 Strengthening EASF Funding Support Source: Field Data, 2019.

One interviewee had this to say:

Funding for EASF operations remains still one of the key challenges facing the organization. If it is on the annual financial contribution, it is based on the GDP of the countries. While Kenya pays over 800 million USD per year, Uganda pays between 400 and 500 million USD while other EASF member states pay even less. This support is not sustainable. EASF has initiated efforts to establish a predictable funding mechanism through securing contributions from international partners like the UN, grants from bilateral sources and the AU to be used to establish the EASF peace fund. The efforts are at different levels of success. (Interview with Key informant, on 20/11/19,Nairobi EASF Headquarters).

The foregoing findings were supported by Bayeh (2014), who argues that, reliable funding is a pre-requisite for effective maintenance of peace and security not only in Kenya and Somalia by the EASF but also in Africa by the ASF. This is reinforced by the fact that successful peace operations and capacity building measures require adequate financing. Lack of funds for ASF in the past had created a problem of dependence on external support. This undermined local ownership of the Force and as a result called into question the role of the ASF as an "African solution to African problems" (Bayeh, 2014).

Munene (2010), observed that in the EASF region, member states had over the years remitted annual contribution to support peace and security initiatives in the region. This was however never adequate, due to their weak internal funding capacities and occurrence of donor fatigue. This in return rendered member states to refrain from actively committing their forces to the regional mechanism for operational deployment due to the mere reason that there were no sufficient funds to reimburse them costs they had incured in such operations. This therefore affected the ability of EASF to address security challenges not only in Kenya and Somalia, but even elsewhere. The assertions had been 
echoed by Allehone (2008), who averred that this kind of scenario discouraged contributions from especially states with less financial capacity, thereby undermining the EASF's multinational effort towards peace and security in the region (Munene, 2015).

One of the initiatives that EASF is employing to overcome this funding challenge was to establish a predictable financial mechanism by establishing a peace fund. The EASF peace fund was established in 2014, through an agreement signed by all the members of EASF. They pledged to establish the EASF peace fund.

By 2015, the EASF fund had received support amounting to $\$ 8.7 \mathrm{~m}$ from member states, while donors had contributed $\$ 2.6 \mathrm{~m}$. This amount was only capable of supporting deployment for 90 days. EASF was however expected to be able to finance a deployment of at least six months, which would be difficult with the current budget. The Fund continues to generate contributions from a variety of sources. They include $12 \%$ of the annual budget, voluntary contributions, and external sources such as the EU's African Peace Facility (Tlalka, 2014).

After operationalization of the fund, EASF was then able to authorize its members to provide for the self-sustainment of their forces for timeframes that vary from 30 days to 90 days for deployment of their standby capabilities in regionally mandated/approved missions. EASF would later use the peace fund to reimburse expenditures incurred by the Troop and Police Contributing Countries (T/PCCs) using the peace fund. EASF would thereafter proceed to finance the mission from the predictable funding instrument. Through the Fund, EASF has managed to secure more predictable and sustainable funding for PSOs and related activities in its endeavour, especially to maintain peace and security in Kenya and Somalia (Tlalka, 2014).

The initiative by EASF to set up a peace fund was motivated by a similar mechanism developed by ECOWAS. Darkwa (2017), observers that a verification of ASF operational readiness that was conducted by $\mathrm{AU}$ in 2013 found that other regions had adopted similar mechanisms. In 2013, the AU Chairperson constituted a panel of experts to assess the operational readiness of the African Standby Force. The team was led by Prof
Gambari. Among the issues to be assessed was the status of funding capability of the REC/RMs. Their report revealed that ECOWAS had already managed to develop a peace fund, which had enabled it to effectively conduct its peace and security activities in West Africa. The region had applied a Community Levy approach, wherein the Commission makes in its annual budget a provision to fund Peace Support Operations through an ECOWAS Peace Fund. The levy is a tax percentage of goods being imported into the region at the rate of $0.5 \%$ of the customs value of the goods. A percentage of the Levy was earmarked for Peace and security operations and kept in the ECOWAS Peace Fund (Darkwa, 2017).

Darkwa (2017), ascertains that the mechanism enabled ECOWAS to also generate finances from donor forums conducted regularly to sensitise partners on the fund and provide overview on its modalities. The idea to start the fund was established after ECOWAS deployed in peace and security scenarios in Liberia, Sierra Leone, Guinea Bissau and Mali in the 1990s and had serious financial challenges to reimburse the participating countries. The situation was made dire by the fact that, despite the operations being mandated by the AU, reimbursements to the REC by the continental body were not forthcoming in time. This became a huge source of frustration to the ECOWAS, especially in the face of consistent demands for reimbursements from the concerned Member States. This informed their decision to set up a peace fund, which has henceforth provided sustainable mechanism to ECOWAS operations (Darkwa, 2017).

\section{* Use of Diplomatic Missions}

The study sought to find out if use of diplomatic missions by EASF would enhance its efforts of maintaining peace and security in Kenya and Somalia. Out of the 255 respondents, 120 $(47 \%)$ of them strongly agreed, 58 (22\%), agreed, while 32 $(12.5 \%)$ and $45(17.5 \%)$ disagreed and strongly disagreed respectively.

Cumulatively, $70 \%$ supported that the effort would enhance EASF effectiveness in maintaining peace and security in Kenya and Somalia. The results are as shown in figure 5.2. 


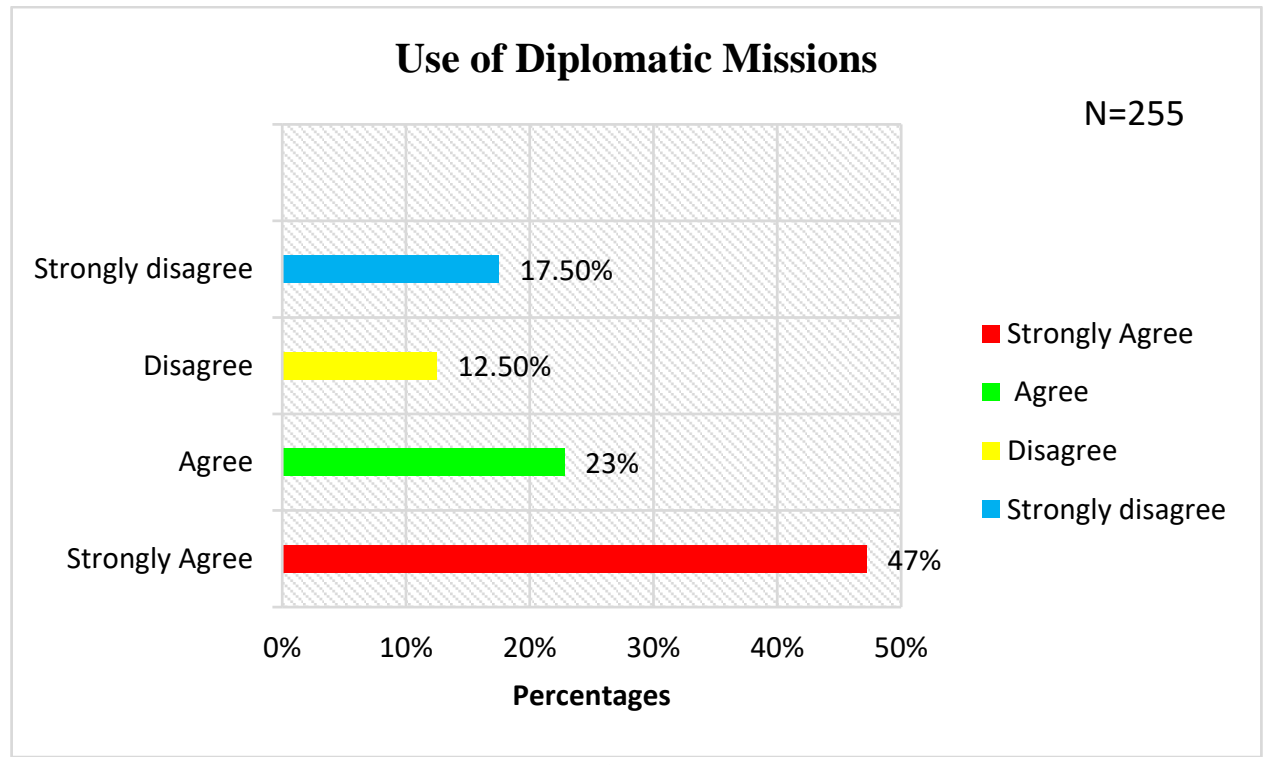

Figure 5.2: Use of Diplomatic Missions Source: Field Data, 2019.

One respondent had this to say:

EASF has a military heavy structure. The concept of military diplomacy therefore, applies in its operations in Kenya and Somalia. The EASF has not adequately employed intensive diplomatic initiatives and missions to address the peace and security concerns in Kenya and Somalia. It has instead cooperated and coordinated its diplomatic efforts with other regional actors and organizations like IGAD and EAC.(Interview with Key informant on 20/12/19,Mogadishu military camp )

The findings are supported by previous study conducted by Migue (2014), which revealed that the concept of military diplomacy was more contextualized within the realm of state defence diplomacy, and less within the wider framework of regional diplomacy. From the foregoing, it does seem logical to argue that military diplomacy is to be seen within the confines of the traditional practice of diplomacy by states. And the question that does arise is, "Does the military conduct diplomacy?" In answering this question one is bound to bring to the fore the peculiar characteristics that define military diplomacy and distinguishes it from the traditional diplomacy alluded to earlier (Migue, 2014).

One may also want to understand how military diplomacy has evolved over the years. Military diplomacy gains relevance considering that diplomacy has experienced a significant transformation particularly in the last decades of the 20th century. Specific reference has been made to the erosion of the barrier of sovereignty, by globalization, revolution in communication and infrastructure, which has cushioned states against interference in their internal affairs by other states and non-state actors. Sovereignty may be the single most vital attribute of the state security. The configuration of the present state system is credited to the 1648 Treaty of Westphalia. The attendant acquisition of sovereignty among states meant that these new units of political organization were equal with no overarching supreme authority to superintend over their relations with each other. In spite of their "equality" however, their relations have been characterized by competing self-interests resulting in what has been called the anarchical international state system (Williams, 2012).

The potential for conflict is therefore, forever present in the international system due to the lack of a common authority. Indeed the main thrust of a state's relations with another is to influence these relations for its own maximum leverage. It is within this influencing that diplomacy gains credence in what Barston (1995), calls, the statecraft of force. This entails such actions as preventing aggression, building alliances, threatening or cautioning an enemy and soliciting for international support for legitimacy and use or control of force. States over time came to the realization that persuasion was critical in their relations. Indeed states became aware that persuasion was usually more successful than the actual use of force. However, the use of the carrot and stick became a useful strategy in determining interstate relations. It is not uncommon therefore, to find the employment of military force to give "muscle" to negotiations (Souza, 2013).

Diplomacy and military force have been used by states and regional security mechanisms for ages and can be seen as the traditional instrument of foreign policy. Used this way, diplomacy is combined with other instruments besides the military to include economics and subversion in what has been labeled as "mixed" diplomacy. In this regard, diplomacy is a communication channel through which the use of threat to use other instruments is relayed to other parties (Robinson, 2014).

One important aspect as regards the EASF was the realization that problems in Kenya of Somalia were not essentially military problems but was also political. As advocated by the deputy chair of the AU, Mr Erastus Mwencha in 2014, these problems therefore, required a mixed approach owing to their complexity. They required a more heavy diplomatic approach, than military. For this reason EASF required to deploy its 
diplomatic initiatives and missions to address peace and security concerns in the two countries; and where there were gaps, EASF was to continue cooperating and coordinating diplomatic missions with other sub -regional organizations like IGAD and EAC.

\section{* Deployment of Peace Support Missions}

This study sought to find out whether deployment of peace support missions would enhance EASF efforts of maintaining peace and security in Kenya and Somalia. From the findings, out of the 255 respondents, $65(26 \%)$ strongly agreed, $78(31 \%)$ agreed, $29(11 \%)$ disagreed and $83(32 \%)$ strongly disagreed.

Cumulatively, $57 \%$ concurred that this activity would enhance maintenance of peace and security in Kenya and Somalia.The results are illustrated in figure 5.3.

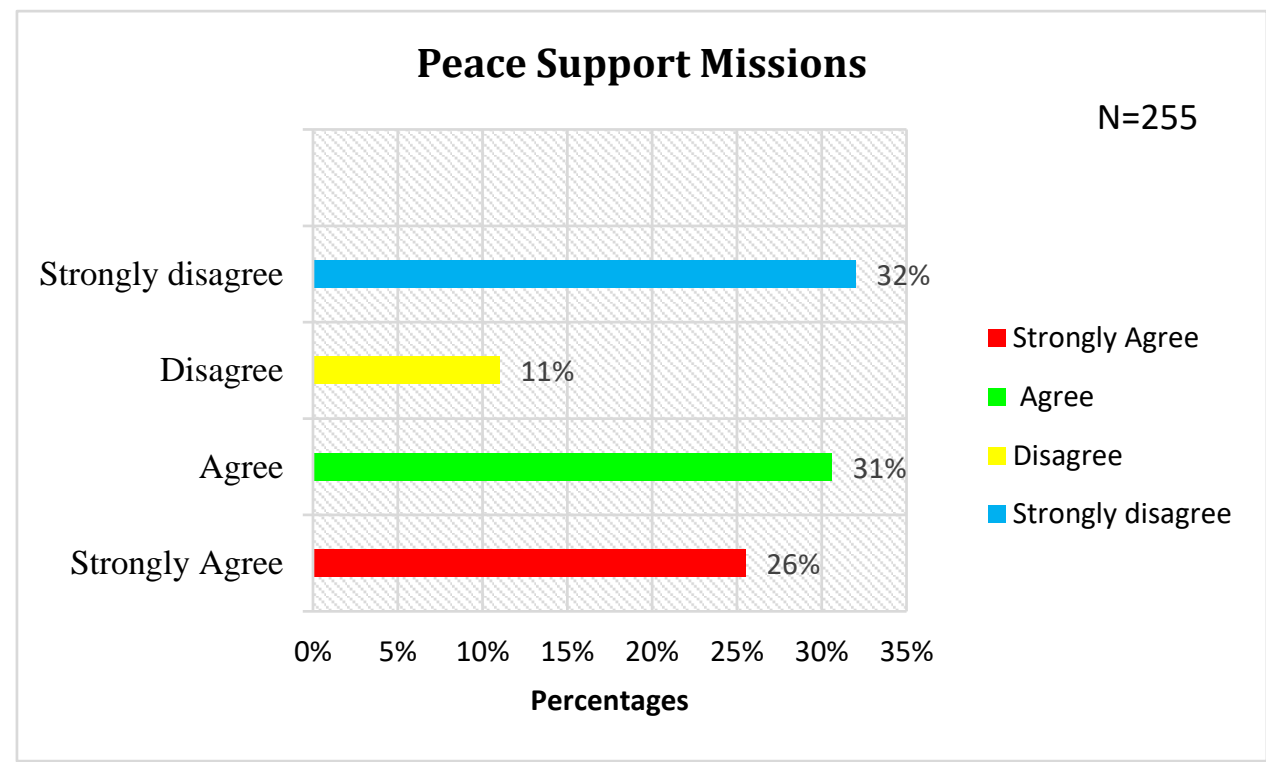

Figure 5.3: Peace Support Missions Source: Field Data.

One respondent from AMISOM underscored the following:

EASF has been engaged in the PSO activities in Somalia but not in Kenya.This is however in the context of the African Union Mission in Somalia.EASF has deployed a 231 police component to AMISOM that was largely composed of East African countries' troops. Albeit small, the EASF police mission is significant in the development of the police dimension of the ASF. EASF has been also incorporated as part of United Nation Political Office for Somalia (UNPOS) and United Nations Support Office for AMISOM (UNSOA). Additionally, on the request of the African Union, EASF carried out a fact-finding mission in Somalia (Interview with Key informant, Date 20/12/19,AMISOM HQs, Mogadishu.)

The finding is supporterd by Aboagye (2012), in his book titled,"A Stitch in Time would have saved nine. Operationalizing the African Standby Force", who underscores the important roles undertaken by peace support missions when deployed in conflict situations. Key among them is the protection of civilians from sexual violence and other vices during armed conflict. They also provide conducive environment for humanitarian agencies to operate and support victims of the conflict. They undertake disarmament; demobilization, reintegration and rehabilitation (DDRR) programs to ensure combatants in a conflict are provided with long-term support. They work with other agencies to provide health care and counselling services for victims of conflict-related sexual violence who are eligible for the DDR programmes. They also assist in the establishment of a secure and peaceful environment for the holding of free, transparent and inclusive elections. To ensure future sustainability they work with other specialized agencies to conduct Security Sector Reforms that ensure new Security Sector mechanisms are put in place to provide Justice and Rule of Law through accountability in conflict situations (Aboagye, 2012).

EASF is fortunate to have members like Kenya that have a long-standing experience in peacekeeping operations and that are capable of contributing immensely to EASF peace support missions to maintain peace and security in Kenya and Somalia. Shah (2009), in his book titled "Conflicts in Africa", observes that the situation between Kenya and Somalia has always been contentious due the latter's policy of irredentism and the occasional incursions of its troops into the Northern Province of Kenya, which is predominantly inhabited by a Somali ethnic population. Tensions between Kenya and Somalia, over the Somali inhabited region occurred right after the independence of Somalia in July 1960. The first Somali independent state declared its intention to unify the Somalia inhabited regions in the horn of Africa under one state in which north eastern province of Kenya was included. Northern Frontier Liberation Army (NFLA), an ethnic Somalia secessionist movement, was established in the early 1960s to fight against Kenyan rule in this region. The Somali government at the time backed up this movement and provided them moral and material support. However in spite of history, 
Kenya has always been friendly with the Somali people since the war broke out in Somalia in 1991. Kenya accommodated the largest number of Somalia refugees who fled the war in Somalia (Shah, 2009).

According to UNHCR Report (2012), Kenya hosted about a half a million Somalia refugees in 2012, but had reduced to two hundred thousand in 2019 due to UNHCR assisted repatriations thereafter. The fact that all conflicts affect regional countries in several ways, the scale of Somali refugees in Kenya could hugely affect this country in variable aspects. This is exemplified by Brown (1996), where in his concept on regional dimensions in internal conflicts, he explains that refugee is a result of internal conflict and it mostly affects the neighboring countries.

Even though Kenya hosts the largest number of Somalia refugees in the world, Kenya's role in the Somali conflict remained quite neutral for many years. Kenya has been involved in mediation processes between Somalia internal actors and has hosted several peace processes meant to reconcile conflicting parts in that country. This includes the one that was held from 20022004 in Mbagathi Conference Centre, Nairobi in Kenya under the auspices of IGAD member states and the international community supporting the Transitional Federal Government (TFG) of Somalia. Regardless of its role in the conflict, Kenya always experienced insecurity incidents posed by this conflict since it broke out in 1991 (Wise, 2011).

The relations between Kenya and Somalia worsened from 2006, due to the changing dimensions of Somalia's conflict. During this time Al-Shabaab armed groups, who controlled larger areas in Somalia threatened to destabilize Kenya. The terrorist organization carried out several attacks inside Kenya targeting tourism and other economic sources of the country. Moreover, the group started to recruit youngsters of Kenya, Somalis in Kenya and other Muslim nationals inside Kenya to join them. The Kenyan government perceived this as serious security threat against its national security and interest. Recruitment of youngsters provided the terrorist organization a capacity to destabilize Kenya through home grown elements. Consequently, the Kenyan government changed its behavior towards the Somali conflict by sending the Kenyan defense forces (KDF) into Somalia to fight Al-Shaabab and prevent their attacks against Kenya. In relation to the dimensions and the behavior of the actors in the Somalia conflict, the conflict can be classified as what Kaldor (2012), explained to be new wars. Recruitment of young men of different nationalities by Al-Shabaab and involvement of AlQaeda terrorists indicated a new war character in this conflict (Kaldor, 2012).

It is against this background that KDF's military deployment in Operation Linda Nchi (2011-2012) against terrorist agents in Somalia is to be contextualized. It is understood that, Kenya joined the community of nations on attaining independence on 12th December 1963 and has a rich history in the field of peace support operations. On 16th December 1963, Kenya became a member of the UN and since then, Kenya has been committed to supporting UN peace initiatives all over the world. Peace Support Operations (PSOs) within the KDF can be traced back to 1973 when the UN requested the Republic of Kenya to contribute forces for peace operations in the Middle East after the Israel-Arab war. However, in spite of Kenya acceding to the request, KDF troops were not deployed due to various logistical constraints. Later within the same decade, KDF started participation in UN PSOs in a career spanning twenty-six missions in sixteen different countries in Africa, the Middle East, the Balkans and in Asia in a period covering over thirty years (Migue, 2014).

In Africa, KDF has participated in various UN PSOs as follows: in former Rhodesia in 1979, in an OAU peace support mission in Chad in 1982, in Angola between 1988 and 1997, in Namibia in 1989, in Western Sahara in 1991, in Liberia between 1993 to1997 and again from 2003 to 2005, in Rwanda between 1993 and 1996, in Mozambique between 1992 and 1995, in Somalia between 1992 to 1995 , in DRC from 1999 to 2001, in Sierra Leone between 1999 and 2003, in the border between Ethiopia and Eritrea between 2000 and 2008, in Burundi between 2004 to 2007 and in Sudan in Darfur from 2005 to date. Other missions include the UN Iran-Iraq Military Observer Group (UNIIMOG) from 1988-1990 and the UN Protection Force (UNPROFOR) in Croatia. Whereas KDF's involvement in the aforementioned missions were PSOs, its engagement in Somalia in October 2011, ushered in a new dimension, that of Peace Enforcement under Chapter V11 of the UN Charter. While in these previous engagements KDF was a neutral arbiter promoting peace, in Somalia, KDF was an interested party to the conflict. The incursion to Somalia was a pre-emptive and preventive campaign aimed at flushing out Al-Shabaab terrorists after series of kidnappings and cross-border incursions into Kenya; hence threatening the security and lucrative tourism industry of Kenya. (Migue, 2014).

This study also proffers that the events leading to the deployment of KDF into Somalia constitute defense diplomacy while KDF's military engagement in Somalia in the period under review constitute military diplomacy. In response to the challenges affecting the national security and interest, the Kenya government increased its involvement in Somalia by integrating the Kenyan forces in Somalia with the AMISOM peacekeeping forces operating under the mandate of the AU and UNSC. The Kenyan forces operating in Somalia initially invaded Somalia with an individual self-defense decision by the Kenyan government under Article 51 of the UN Charter. The AU and UNSC officially allowed KDF to join AMISOM peacekeeping forces through in UNSC resolution 2036 of February 2012. The resolution provides legal framework, mandates and resources to the Kenyan forces to fight Al-Shabaab in Somalia (Migue, 2014).

In order to protect its own national security, Kenya strives for peace and stability in Somalia, particularly in the nearby regions of Juba land. Therefore, in order to get security in her territories, an active Somali regional state in the nearby regions is an option for Kenya in the context of Jubaland. This friendly region creates a security buffer zone to protect Kenyan national security and interest. Moreover, Kenya argues that such an authority can create a safe and secure environment for Somalia refugees living in Kenya to return and resettle in their country (Erickson, 2013). 
Even though Somalia's conflict has prolonged and passed through different dimensions and multiple identities, the intervention by neighboring states such as Kenya and Ethiopia can lead the conflict to a new dimension with new identities based on regional states. The behavior of Kenya in this conflict is unlikely to produce a holistic solution for Somalia's conflict; it rather focuses on a partial solution in which its national interest is bounded. Even though, Kenya explained this is an action of defensive intervention which, Williams (2018), explains to be when states intervene others' conflicts with the objectives of selfdefense and target to bring cross-border problems, such as refugee flows or military assaults to an end, to keep wars from spreading or more ambitiously, to bring wars to an end (Williams, 2018).

As highlighted by the respondents, the EASF has so far made some efforts to deploy a peace support mission in Somalia but to a limited extent, in the context of the African Union Mission in Somalia (AMISOM). In 2011, the EASF deployed a 231 police component to AMISOM, though it was composed not only of East African countries' troops. Albeit small, the EASF police mission was significant in the development of the police dimension of the ASF. What is more, the EASF was also later incorporated as a part of United Nation Political Office for Somalia (UNPOS) and United Nations Support Office for AMISOM (UNSOA). Additionally, on the request of the African Union, EASF carried out a fact-finding mission in Somalia in 2011.These are encouraging steps toward EASF efforts of maintaining peace and security in Kenya and Somalia (Abdow, 2012).

\section{* Enhancing Mediation Capability}

It has been observed throughout Africa, that traditions have since time immemorial emphasized on harmony or togetherness over individual interests and humanness. This was expressed in terms such as Ubuntu (meaning humanity in Bantu Nguni language) in South Africa and Utu (meaning humanity in Swahili language) in East Africa. Such values have contributed to social harmony in internecine African societies and have been innovatively incorporated into formal justice systems in the resolution of conflicts. In this way conflicts have been averted and where they have arisen, there have been mechanisms and institutions that have been put in place to effectively resolve them through mediation without resorting to fighting.

It is against this background that the study sought to find out if enhanced EASF mediation capability would contribute to its efforts to maintain peace and security in Kenya and Somalia.

As illustrated in figure 5.4, out of the 255 respondents, 77 $(30 \%)$ of the respondents strongly agreed that this would help a lot, $51(20 \%)$ agreed that this would help. 99 (39\%) disagreed and $28(11 \%)$ strongly disagreed. Cumulatively therefore, $50 \%$ agreed that enhanced EASF mediation capability would contribute immensely to EASF efforts of maintaining peace and security in Kenya and Somalia.

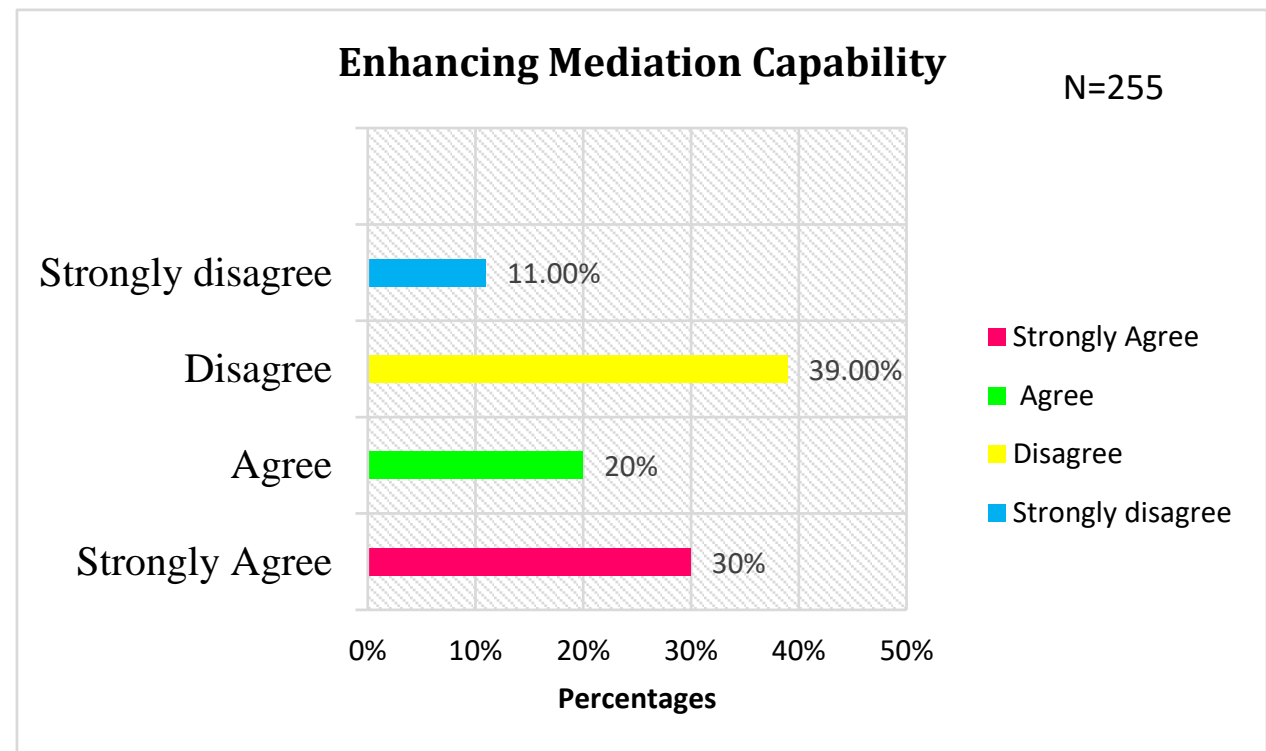

Figure 5.4: Enhancing Mediation Capability Source: Field Data, 2019.

The findings are collaborated by Abdow (2010), in his book titled "The factors that influence the extent to which community leaders play their role in conflict resolution". He argues that ttraditional conflict resolution mechanisms like the adjudication and cross-examination processes among the Yoruba in Nigeria were employed whenever intercommunal differences arose. This was because they offered great prospects for peaceful co-existence. It was therefore, imperative that traditional conflict management mechanisms were harnessed to manage conflicts, as they were more of resolution mechanisms rather than settlement initiatives, in the wider context of mediation (Abdow, 2010).

He argues that African societies have used mediation processes to resolve conflicts for hundreds of years. It was used informally where disputants could just sit with a third party such 
as the council of elders who could facilitate the mediations. However, the formal legal system has failed to recognize that mediation is not a new concept and has tried to classify mediation as part of the Alternative Dispute Resolution mechanisms. It views mediation as an alternative to litigation. This view of mediation is flawed as it gives mediation a second place in the conflict settlement continuum. Mediation can stand alone as a method of resolving conflicts. Care has to however to be taken to ensure that parties enter into mediation voluntarily. With this the outcome of the process is respected and the solutions reached are acceptable and enduring to all parties to the conflict (Abdow, 2010).

Menkhaus (2005), while alluding to protracted conflict in Somalia,acknowledges that mediation processes, if carried out correctly leads to outcomes that are desirable to all parties and are enduring. This is because parties have autonomy over the process and the outcome. Parties who have a conflict may decide to negotiate. When negotiations hit a deadlock they get a third party to help them continue with the mediation. The mediator's role in such a process is to assist the parties to keep engaging, throughout. $\mathrm{He}$ or she does not dictate the outcomes of the mediation. Parties must have the autonomy of the process and of the outcome since it is a voluntary process. When the voluntariness is lost then the process of mediation is negatively affected. The parties are expected to report back the outcome of their mediation to court for it to endorse it. It is however important to ensure that the process is not exposed to the vagaries that bedevil the court system including delays, bureaucracy and inefficiency (Abdow, 2010).

The concept of utilizing mediation as a mechanism to resolve conflicts was adopted by EASF, as one of its key conflict resolution initiatives at its establishment. Conflict situations were in the region were initially being addressed by the West, but following the end of the Cold War, the West became disinterested and attached many conditions before being involved in any conflict in Africa. A combination of factors explains this attitude. The main one was the death of 18 USA marines in Mogadishu and the chaos that engulfed the Balkans in the 1990s, diverting Western attention. This neglect manifested itself in the lack of intervention in the Rwandan genocide, Liberia and Sierra Leone in the 1990s. It is this situation that saw intervention by ECOWAS in Liberia, which set a precedent for sub-regional interventions (Agaypong, 2005).

This led the debate on sub-regional intervention. The debate was dominated by two contradicting views. Whereas Nye (2011), in his book titled," The Future of Power", supports the approach, to use sub regional organizations to resolve regional conflicts, others argued on the contrary. He further contended that sub-regional organizations were better placed because they were nearer to the conflict and could afford to stay long after an agreement to stabilize the situation has been signed. Equally, subregional organizations have the advantage of understanding the conflict better and had relationships with the parties to the conflict. Those who contended this view however, argue out that subregional organizations lack the resources and capacity for intervention (Nye, 2011).

The opposing side of the debates argued that because of their proximity to the conflict such organizations were entangled with the conflict to the extent that, they lacked the legitimacy that an international intervention would have.

IGAD's intervention in Somalia in 2005, when viewed from this perspective had the advantage of an in-depth knowledge of the conflict and relationship with the parties to the conflict. But it also had serious shortcomings; with the main one being lack of resources. To overcome this problem, IGAD partnered with the International Partner Forum (IPF), comprising of a consortium of countries willing to provide resources towards the resolution of the Somali conflict responsibility to sub-regional organizations (Williams, 2011).

However, throughout the dabate, mediation has been accepted as an important aspect of not only resolving conflict but also for peace building. If properly utilized, it could achieve not just a settlement of conflict but facilitate a full transformation of relations. If peace building is defined as identifying and supporting those structures that can strengthen and solidify peace in the aftermath of peacemaking and peacekeeping, then peace building encompasses a range of activities and structures before, during and after formal peace agreements between parties are signed. It is also therefore a dynamic process of resolving conflict and rebuilding societies involving mechanisms and structures that can prevent, terminate, transform or resolve conflict. It further involves mechanisms and structures that can strengthen the capacity of a society to manage change without violence. This may involve addressing the root causes of conflict through long-term economic and social provisions as well as policies of reconciliation. There is a growing recognition of the potential of mediation outside its traditional role in conflict resolution (Vines, 2013).

Souza (2013), observes that the Organization for Economic Cooperation and Development (OECD), which is a group of 34 member countries that support free-market economies in the world also encourages mediation as a way of strengthening the resilience capacity of states and state-society relations. Important elements include supporting dialogue processes between civil society, the private sector and state institutions. Mediation initiatives have also strengthened private sector investment in Bosnia and Herzegovina. Between 2004 and 2006, local mediators resolved disputes between companies and thereby facilitated the release of $€ 8$ million in private-sector investments (Vines, 2013).

Robinson (2014), further observes that examples abide on the potential gains of mediation support activities for economic development. He reckons that the value added of current mediation practice provides important insights into strengthening political accords and economic conditions in war-to-peace transitions. For this reason, defining a role for development agencies as strategic partners for peacemaking is therefore an important element to managing the transition from war to peace. Their engagement during peace process helps create a new vision of the economy and society that convinces parties that it is worthwhile to stop fighting. If a future without armed conflict becomes a more viable reality, the parties to a peace process may increase their commitment in negotiations as companies commit to post-conflict economies before the signature of a peace agreement. In addition, development actors can marshal important 
financial flows into conflict countries that could be used as incentives for peace, an arrangement used by EASF in Kenya and Somalia (Robinson, 2014).

Bouka (2016), in his book titled,"Missing the Target: The African Union's Mediating Efforts in Burundi" observed that since conflict is dynamic and unavoidable in the East African region, EASF has been involved in a number of conflict mediation interventions, albeit few. He underscores the role-played by EASF in mediating the 2015 Burundi crisis. This was after late president Nkurunziza decided to run for a controversial third term in office. EASF was supposed to deploy in Burundi as part of the African Prevention and Protection Mission in Burundi (MAPROBU), However, in December 2015,three members of the AU PSC, that were also members of the EASF, namely Uganda, Ethiopia and Burundi became very instrumental in undertaking mediation initiatives among the opposing parties in Burundi. The mediation efforts team was headed by the defence minister of Uganda, $\mathrm{Mr}$ Kiyonga. This contributed to easing of tensions in the country (Bouka, 2016).

EASF has played significant roles in offering mediation forums for Somalia during its long period of instability and also in Kenya, especially during the 2007/2008 Kenya's post-election violence (PEV). In 2019, EASF was also working closely with IGAD, whose chair, the Prime Minister (PM) of Ethiopia, Dr Abiy, was leading mediation efforts between Kenya and Somalia to resolve the maritime dispute between them. Though the case still remains at the International Court of Justice (ICJ), such regional meditation efforts were taking place to resolve the issue amicably. EASF has also partnered with other regional organizations like IGAD and ICGLR to promote peace and security in Eastern Africa region through various mediations efforts. These EASF mediation efforts especially in Kenya and Somalia have made things much better because prior to the end of the Cold War, interventions in Africa and especially in the Eastern Africa Region, were determined by allies, either from the Eastern bloc, led by the Soviet Union, or Western bloc led by the USA (Derroso, 2010).

Munene (2015), in his book titled "A Look at the East Africa Standby Force", observes that EASF has attempted to unearth dozens of underlying factors that contribute, as well aggravate Kenya-Somalia relations through a number of mediation efforts. By and large, this effort has assisted to address the issue of refugee flows, humanitarian crises, arms cross border flows and Islamist terror attacks that have strained and compounded the Kenya-Somalia peace quest.

This supports the finding that an enhanced EASF mediation capability will therefore greatly improve EASF efforts to maintain peace and security in the region and especially in Kenya and Somalia (Munene ,2015).

\section{CONCLUSION}

The study concludes that, despite positive efforts by EASF to promote its capacity to maintain peace and Security in Kenya and Somalia, collaborative efforts with other actors have been lukewarm and lacking in synergy. Therefore EASF, like other regional security mechanisms has a responsibility to seek and coalesce with other mechanisms under APSA in order to realize its full mandate potential.

\section{RECOMMENDATION}

The study recommends EASF establish a real-time monitoring and accountability framework that should aid it in fast tracking the initiatives put in place for fostering peace and promoting security in Kenya and Somalia. This involves putting in place multi-pronged efforts to dissemble the impeding factors towards peace and security in Kenya and Somalia.

\section{REFERENCES}

[1] Abdow, A. (2010). The factors that influence the extent to which community leaders play their role in conflict resolution: a case of Mandera district in Kenya. Unpublished research project report for Masters of Arts in project planning and management, University of Nairobi. 2010.

[2] Aboagye, F. (2012). A Stitch in Time Would Have Saved Nine. Operationalizing the African Standby Force. Institute for Security Studies Policy Brief no $34 . \quad$ Available at:http://www.issafrica.org/uploads/ASFPolBrief.pdf [Accessed: 12 January 2020].

[3] Agyapong, W.(2005). "Military Intervention in Intrastate Conflicts in West Africa: Economic Community of West African States Monitoring Group as a Case Study." Thesis, US Army Command and General Staff College, 2005.

[4] Allehone M (2008). "Promises and Challenges of a Sub-Regional Force for the Horn of Africa”, International Peacekeeping, vol.15 (2), pp. 171184.

[5] Barnett, Michael and Duvall, Raymond (2005). 'Power in International Politics', 39-75.

International Organization, 59 (1)

[6] Bayeh,E.(2014).THE Eastern Africa Standby Force: Roles, Challenges and Prospects. International Journal of Political Science and development ,Vol.2(9),pp.197-204.

[7] Berenskoetter, Felix and Williams, M. J. (eds) (2007). Power in World Politics. London: Routledge.

[8] Bouka, Y(2016). Missing the Target: The African Union's Mediating Efforts in Burundi, $\quad$ Egmont Institute, Africa Policy Brief, June 2016.

[9] Brown, Michael E. (1996). The International Dimensions of Internal Conflict. Center for Science and International Affairs. John F Canady School of Government, Havard University, Cambridge. Massachusetts.

[10] Creswell, JW. (2009). Quantitative \& Qualitative Research. Thousand Oaks, CA: Sage Publication.

[11] Darkwa,Linda (2017).African Standby Force.The African Union Tool for the Maintenance of Peace and Security-On line Journal-Routledge \&Frncis Group 2017.

[12] Derosso, S. A. (2010,). The role and place of the African standby force within the African peace and security architecture. Institute for security studies paper, 209. Pretoria: Institute for Security Studies(2010).

[13] Eriksson, Mikael (2013). Somalia's Civil War, Security Promotion and National Interest. Swedish Defense Research Agency FOI-R-3718-SE. ISSN 1650-1942. Mainstay of defense.

[14] Gilpin, Robert (1981). War and Change in World Politics. New York: Cambridge University Press.

[15] Guzzini, Stefano (2000).'The Use and Misuse of Power Analysis in International Theory', in Ronen Palan (ed.), Global Political Economy: Contemporary Theories. London: Routledge pp 53-66.

[16] Kaldor, Mary. (2012). New and Old Wars. 3rd edition, Stanford University Press: Stanford, California 
[17] Lindberg, L. (1963). The Political Dynamics of European Economic Integration (Stanford, CA: Princeton University Press). This is also a neofunctionalist classic. While Haas (1958) focused on the ECSC, Lindberg here concentrated his analysis on the EEC.

[18] Menkhaus ,K.(2005) Somalia in 2005 : No exit . Annales d'Éthiopie Année pp. 73-84.

[19] Migue, T.P. (2014). Military Diplomacy: A Case Study Of Kenya Defence Forces In Somalia (2011-2012): University Of Nairobi Press.

[20] Morgenthau, H. J. (1960). Politics Among Nations: The Struggle for Power and Peace, 3rd edn. New York: Alfred A. Knopf.

[21] Munene, M.(2015). A Look at the East Africa Standby Force, EASF: EASF International Peace Day.

[22] Nzau, M. (2016). Transitional Justice and After: Kenya's Experience with IDP Resettlement and Peace building since the 2007/2008 PostElection Violence. Nairobi: CUEA Press, 2016.

[23] Nye, J. (2011). The Future of Power. New York: Public Affairs.

[24] Orodho, A. J. (2003). Essentials of educational and social sciences research method. Nairobi: Masola Publishers.

[25] Robinson C (2014). "The Eastern Africa Standby Force: History and Prospects", International Peacekeeping, pp. 1-17.

[26] Shah, A. (2009). Conflicts in Africa, Introduction, content available at http://www.globalissues.org/article/84/conflicts-in-africa-introduction, accessed on 10th August 2015.

[27] Sousa R (2013). "African Peace and Security Architecture (APSA) Subsidiary and the Horn of Africa: The Intergovernmental Authority for Development (IGAD)", Lisbon: University Institute of Lisbon.2013
[28] Tlalka, K.,(2014). "East African Satndby Force, Shortcomings and prospects for the future": Centro de Estudos Internacionais do Instituto Universitário de Lisbon.2014.

[29] UNHCR (2012). Refugee Population in Kenya. (http://www.unhcr.org/cgibin/texis/vtx/home) Accessed: May.21-2019.

[30] Vines, A. (2013). "A Decade of African Peace and Security Architecture", International Affairs, vol. 89 (1), pp. 89-109.

[31] Williams, P. D. (2011). “The African Union's Conflict Management Capabilities."

[32] Working Paper. International Institutions and Global Governance Program. Accessed on 20 October 2019 from http;//www.swp

[33] Williams, P. D. (2012). The Peace and Security Council of the African Union: Evaluating an Embryonic International Institution// 47 Journal of Modern African Studies 603,620.2

[34] Williams, P. D. (2018). "Fighting for peace in Somalia:A History and analysis of the AMISOM from 2007-2017.Oxford University Press,UK,2018.

[35] Wise, R. (2011). The Al-Shaabab Case Study Number 2.Centre for Strategic Studies and International Relations, London.2011.N

\section{AUTHORS}

First Author - Robert Gichangi Kabage, Department of Peace and Conflict Studies, P.O Box 190-50100, Kakamega

Second Author - Prof.Kennedy Onkware, Department of Peace and Conflict Studies, P.O Box 190-50100, Kakamega

Third Author - Prof.Crispinous Iteyo, Department of Peace and Conflict Studies, P.O Box 190-50100, Kakamega 